\title{
Stanisław Tokarczuk (red.), Rudna. Ilustrowana monografia gminy, Stowa- rzyszenie Animatorów Kultury i Edukacji \& Agencja Artystyczna „Codex”, Lubin 2012, ss. 330
}

DOI: 10.14746/BHW.2014.31.16

Publikacja Rudna. Ilustrowana monografia gminy z 2012 r. jest drugą edycją opracowania, wydanego po raz pierwszy dwa lata wcześniej. Jej powstanie zawdzięczamy zespołowi autorów, w którego skład weszli: Danuta Adamska, Halina Jakubowska, Krzysztof Kułacz, Krzysztof Próchnicki, Magdalena Stefanowska, Stanisław Tokarczuk i Alina Zawadka.

Już sam tytuł jasno określa, że mamy do czynienia z monografią, czyli pracą analityczna, która daje zwykle wyczerpujacy opis jednego wybranego zagadnienia, poprzez wszechstronna krytykę literatury i źródel, oraz ich interpretację. Praca monograficzna zawiera odtworzenie faktów i pogląd na analizowane zagadnienie, będacy wyrazem krytyki stanu badań i materiału źródłowego ${ }^{1}$.

Dr Stanisław Tokarczuk, redaktor i współautor opracowania, zarówno z racji wykształcenia, jak i doświadczeń edytorskich, był osobą predestynowaną do pokierowania pracą zespołu, przygotowującego opracowanie o charakterze monograficznym. Posiadając profesjonalne przygotowanie pedagogiczne, historyczne i socjologiczne, zadbał o to, by publikacja zawierała materiały prezentujące opisywany rejon, zgodnie z przytoczoną powyżej definicją, rzeczywiście w sposób wyczerpujący i wszechstronny. Natomiast jako regionalista, od lat 80 . XX w. wydający publikacje z zakresu historii i współczesności swej małej ojczyzny (Wypisy z piastowskich annałów Lubina. Legendy, fakty $i$ watpliwości, 1989; Lubin. Zarys rozwoju miasta na przestrzeni wieków, 1996; Monografia gminy wiejskiej Lubin, 1997; Kościół Grzebalny w Starym Lubinie, 2000 i inne), posiadł doświadczenie, które pozwoliło zaprezentować zgromadzone materiały w sposób przejrzysty i atrakcyjny. Oba te aspekty, czyli wszechstronność ujęcia i atrakcyjna forma, cechują więc charakteryzowaną publikację.

Praca Rudna. Ilustrowana monografia gminy podzielona została na następujące rozdziały, omawiające obszernie tematykę zakreśloną w tytule każdego z nich: 1. Środowisko geograficzno - przyrodnicze gminy Rudna, 2. Wybrane fakty z dziejów ziemi rudnowskiej, 3. Kronika społeczności lokalnych (prezentujący szczegółowo poszczególne miejscowości i wsie wchodzące w skład gminy), 4. Dramatyczne czasy II wojny światowej, 5. Kwestie demograficzne w gminie Rudna, 6. Współczesność gminy Rudna oraz Suplement (zawierający między innymi biogramy znanych postaci złączonych różnorodnymi więzami z nadodrzańską ziemią). W porównaniu z I wydaniem niewielkie zmiany pojawiły się w układzie tekstu i w ikonografii trzeciego rozdziału. Istotną nowością jest ponadto, zawarty w „Suplemencie”, opis wydarzeń związanych z powodzią, która dotknęła Dolny Śląsk w 2010 r.

\footnotetext{
${ }^{1}$ B. Miśkiewicz, Wstęp do badań historycznych, Warszawa - Poznań 1988, s. 192.
} 
Dobór treści zawartych $\mathrm{w}$ charakteryzowanej monografii jest, jak wspomniano, wszechstronny, a ich układ logiczny. Każdy z czytelników, zależnie od preferencji, znajdzie w książce materiały i wiadomości, które szczególnie go zainteresują. Jednak niewątpliwie jednym z najciekawszych elementów publikacji jest fragment opisujący wydarzenia, które nastąpiły bezpośrednio po zakończeniu II wojny światowej. Obszar gminy Rudna, jak zresztą cały teren tzw. Ziem Odzyskanych, radykalnie zmienił swe oblicze etniczne - na miejsce dotychczasowych gospodarzy, czyli Niemców, przybyli polscy „,repatrianci”, pochodzący zarówno z Kresów Południowo-Wschodnich, jak i z Polski Centralnej. Proces ten, charakterystyczny dla wszystkich terenów, które przypadły Polsce w wyniku decyzji Wielkiej Trójki, na ziemi rudnowskiej zyskał dodatkową dramaturgię przez fakt, że właśnie tutaj przesiedlono z Podbeskidzia i z Bieszczadów, w ramach akcji „Wisła”, sporą grupę Ukraińców (przez to pojęcie skrótowo ujmujemy także społeczność łemkowską, która wewnętrznie nie jest całkowicie jednomyślna w kwestii przynależności do narodu ukraińskiego). Stosunki polsko-niemiecko-ukraińskie czasu II wojny światowej i przesiedleń okresu powojennego są powikłane, niejednoznaczne, pełne wzajemnych oskarżeń i głęboko zakorzenionego poczucia krzywdy. Autor opracowania, opisując zagadnienie, prezentuje w kwestiach kontrowersyjnych jasne i jednoznaczne opinie, które z pewnością nie znajdą akceptacji u każdego z czytelników. W takiej sytuacji pojawia się pytanie, skądinąd tak stare, jak sama historia jako dyscyplina naukowa: czy historyk ma prawo do wyrażania oceny i zajmowania stanowiska, czy też jego powinnością jest jedynie rzetelny opis prezentowanych zagadnień? Wydaje się, że sposobem na rozwiązanie tego dylematu jest wyraźnie oddzielanie faktografii od komentarza. Taką metodę zastosował redaktor monografii: jakkolwiek pewne sprawy ocenia jednoznacznie, to jednak primo: rzetelnie przedstawia złożoność i kontrowersje związane $\mathrm{z}$ opisywanym zagadnieniem, secundo: uczciwie prezentuje poglądy swych adwersarzy, zamieszczając wskazówki bibliograficzne kierujące do ich publikacji. Takie ujęcie jest niewątpliwie mocną stroną opracowania.

Na marginesie prezentacji publikacji Rudna. Ilustrowana monografia gminy nasuwają się dwie refleksje. Pierwsza, o charakterze ogólnym, dotyczy kapitalnej roli, jaką dla prawidłowego przebiegu procesu edukacji regionalnej (local education) ma tworzenie i publikowanie monografii regionalnych prezentujących wysoki poziom merytoryczny, a przy tym atrakcyjnych od strony edytorskiej. Przez pojęcie edukacji regionalnej rozumiemy przy tym wprowadzenie w tradycję i aktualne życie społeczno-kulturalne regionu i środowiska lokalnego, polegające na pedagogicznym ułatwieniu zaistnienia jednostek i małych grup społecznych jako podmioty życia spolecznego i spoleczno-gospodarczego i urzeczywistnienia swoich aspiracji poprzez wspólne wykorzystanie zastanych $i$ wytworzonych zasobów przyrodniczych, gospodarczych, spotecznych i kulturalnych ${ }^{2}$. Jako że proces ten nie dotyczy jedynie dzieci i młodzieży, ale jest elementem wychowania permanentnego, a przy tym wpływa na kształtowanie postaw niezbędnych dla prawidłowego funkcjonowania społeczeństwa w skali mikro, pojawianie się na rynku wydawniczym

2 D. Jankowski, Edukacja regionalna jako czynnik regionotwórczy, w: S. Dąbrowski, A. Kociszewski (red.), Regionalizm polski, Ciechanów 1990, s.107. 
takich publikacji, jak Rudna. Ilustrowana monografia gminy jest faktem ze wszech miar godnym uznania.

Refleksja druga, bardziej szczegółowa, związana jest ze specyfiką edukacji regionalnej przebiegającej w społecznościach, których mała ojczyzna leży na ziemiach, jakie znalazły się w granicach naszego państwa w wyniku konferencji jałtańskiej. Taką właśnie społecznością są mieszkańcy gminy Rudna, a local education ma tutaj znaczenie szczególne ze względu na fakt, że jako przesiedleńcy lub ich potomkowie w pierwszym lub drugim pokoleniu, Rudnianie doświadczyli procesu wykorzenienia socjokulturalnego. Znaleźli się z dala od ziemi, na której od wieków kultywowano miejscowe zwyczaje i obrzędy. Spotkali przybyszów z innych rejonów, także odciętych od źródeł tradycji. Sytuacja wykorzenienia nie sprzyja rozwojowi żywej i kreatywnej tkanki społecznej, niezbędnej dla prawidłowego funkcjonowania i rozwoju regionu. $\mathrm{W}$ takich okolicznościach rozwiązaniem może być dogłębne poznanie historii nowej ojczyzny. Okazuje się, że wiele elementów tej spuścizny przybysze mogą „oswoić” i z pożytkiem wykorzystać dla stworzenia własnych i swoistych zwyczajów oraz tradycji.

Książka Rudna. Ilustrowana monografia gminy jest próbą (dodajmy - zakończoną sukcesem, o czym świadczy fakt, że recenzja niniejsza dotyczy wydania II; pierwsza edycja spotkała się bowiem ze znacznym zainteresowaniem czytelników) przyswojenia obecnym mieszkańcom wielowiekowej, bogatej historii tej ziemi. Co oczywiste, bowiem aby coś zaakceptować i przyjąć jako swoje, trzeba to najpierw dobrze poznać; monografia rudnowska daje czytelnikowi szansę na poznanie wnikliwe oraz wszechstronne. $\mathrm{Na}$ ten sukces wpływ ma okoliczność, że sami autorzy opisywaną ziemię znają i kochają. Rzecz tym bardziej godna uznania, że przecież i oni są w Rudnej oraz okolicach przesiedleńcami lub ich potomkami. Redaktor opracowania urodził się i pierwsze lata życia spędził w Czaharach Zbaraskich; fakt silnego przywiązania „Zabużan” do swych dawnych siedzib jest powszechnie znany. Jeśli więc jeden z potomków rycerstwa znad kresowych stanic tak dogłębnie poznał swą nową małą ojczyznę i obdarzył ją tak pieczołowitym przywiązaniem, to oznacza, że ziemia rudnowska (tak samo jak inne małe ojczyzny leżące na Dolnym Śląsku, Wschodnich Łużycach, Ziemi Lubuskiej, Pomorzu Zachodnim, Warmii i Mazurach) niewątpliwie zasługuje na to, by zgłębić jej historię i współczesność. Zaś praca Rudna. Ilustrowana monografia gminy może się stać tego poznania użytecznym narzędziem.

Tomasz Fetzki 